\title{
The Necessity for Building Un-Armoured Ships of War
}

\section{Captain W. Horton R.N.}

To cite this article: Captain W. Horton R.N. (1866) The Necessity for Building UnArmoured Ships of War, Royal United Services Institution. Journal, 10:38, 1-36, DOI: 10.1080/03071846609417195

To link to this article: http://dx.doi.org/10.1080/03071846609417195

册 Published online: 11 Sep 2009.

Submit your article to this journal $₫$

Џll Article views: 1

Q View related articles 5 


\section{The Sortual}

OF THE

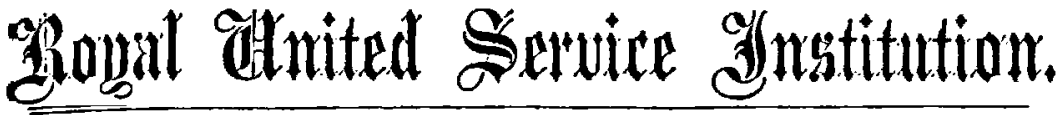 \\ VoL. $\mathrm{X}$. $1866 . \quad$ No. XXXVIII.}

\section{(Ébernitry atellecting.}

Monday, January 15th, $186 \mathrm{~b}$.

Gaptaix E. Gardiner FishbouRNe, R.N., G.B., in tho Chair.

NAMES of MEDMBERS who joined tho Institution betwean the 1st and 15th January, 1866.

$\triangle N N U A L$.

Jackson, J. II., Ersign 00th Regiment. Clementson, Charles, Lieut.-Col., Fior * $1 l$.

Bcadon, O. A., Lieut. Rojal Mariuc

right Infantrs. $1 l$.

Durrant, F., Lieut. R.N. 11. thumberland Artillery Militia. $1 l$.

Robinson, C.T., Lieut. Rifle Brigade. $1 l$.

IIontgomerie, A. W., Capt. 20th Hussars. $1 l$.

\section{TIE NECESSITY FOR BUILDING UN-ARMOURED SHIPS OF TTMR.}

\section{By Captain W. Hontox; R.N.}

Alneadr twice within twelve years havo wo heard of reconstruction of the British Nary.

Considerations of improved efficiency of individual ships on the pattern, more or less, in either case, set before us by the French, have led to theso expensivo changes which lare been followed in their own degrees by other European nations.

The remaining navies of Europe, that of France excepted, have been hitherto inconsiderable; but the same means of improvement adopted elsewhere, and consequently thrust upon this country, hare rendered almost equally powerful with the flect of France, those of both Italy and Russia. Iron-clad ships hare also found farour in Austria, and eren in Turkey, while the restoration of the Spanish Nary to a prominent position is a very popular idea in that country, and not unlikely to be fulfilled under the rapidly increasing wealth and prosperity of a kingdom which numbers upwards of 60,000 enrolled seamen along he: $\Lambda$ tlantic and Mediterranean consts. 
I mentioned considerations of efficiency of ships as having led us on to reconstruction, first in establishing a maguificent force of ships of the line, and powerful frigates and corvettes propelled by stearn, then in calling into existence a number of iron-clads, which has ever and anon been counted orer and compared with those of France, people being content in general to measure our strength according to that of our ancient adversary - our recent rival and ally-and to omit from the question altogether political combinations which, were they to arise in less quiet times than these, might bring into array against us a vastly superior force of those expensive and now much-criticised ironciad ships. With properly armed and efficiently turretted armour-ships, supplemented by the porverful forts and batteries now in course of construction or completion, and yet farther aided by a properly organised system of torpedo defence, we may trust, under Providence, to defy as heretofore, the attack of our own shores by the world in arms.

In the years, however, which have elapsed since the invasion of this country was happily averted by our great naval triumphs of the last generation, so great a change lias come over the nature of our colonial possessions, colonial population, and maritime commerce, that political considerations of a different character cannot fail, ere long, to dictate the nature of such changes as we must see, take the place of the two recent re-constructions.

Re-formation, or re-organisation would be moro fitting terms tó apply to that which must soon and surely ensuc, including a speciality of certain classes of ships adapted for certain services.

We witnessed during the late lamentable strife between the Federal, and Confederate States of North America, what serious injury could in a short time be inflicted upon the extended conmerce of their powerful adversary, by a comparatively weak confederation, possessing no navy whaterer, through the skilful employment of some small and indifferent vessels, stirreptitiously obtained from this country.

The Nortliern conmerce was completely paralysed by the seeming ubiquity of the "Sumter," the "Alabama", and a few moro casual cruizers, all of a very inferior description. The fixed determination of purpose which enabled the North to prevail at length, after four Jears' strife, and to maintain the Union whose disruption was at stake, caused the aduption of wise measures for carrying that purpose into effect, and all sacrifices at sea were unresistingly borne with, in order that the blockade of the Southem coasts might be maintained as efficiently as possible.

The lesson learnt at such prodigious cost was not thrown away upon the hard-headed, astute statesmen who hold high office in the United States, and who carry vigorously into effect whaterer measures they deem to be for their country's welfare.

Accordingly, before the war was at an end, it was determined to establish a class of vessels for foreign serrice possessing great speed, and carrying very heary guns, which, if they at all approach the idea upon which they were designed, will have it in their power, so long as they continue unopposed by more numerous ships of superior, or at least of equal sieed and armament, effectually to sweep the seas of any conmerce against which they may be launched. Such ships will 
be fit to fight on favourable terms when the occasion may arise, and able to. Aee beyond possibility of capture, from any description of ressels now existing elsewhere, and which might happen to carry a superior armament or thicker sides. Having for their object the annihilation of our enemy's commerce on the sea, they would scarcely stop in their "Alabama"-like career of depredation to measure their strength against an adversary better armed than themselres.

Viewing this statement from the opposite side, it would appear that in competition with such ships, any that re now possess would be eqally unfit to fight them when such might be their policy, and incapable of overtaking them if they chose to run away. The conditions of a contest between opponents thus unequally matched are such as cannot be contemplated with much satisfaction from our view of the case, as it now stands.

In pursuing this policy, the Americans are following out the principle which has erer governed their naval administration. Since they were a nation, it has been their object to possess some one class of ressels enjoying a manifest superiority over the corresponding class in our Navy.

Wo suffered in bygone times irom their use of long guns, as opposed to carronades, and from their employment of heary frigates, with which we had none fit to compete on equal terms.

The gallant action of the " Endymion" with the "President," and the noble heroism which made the "Chesapeake" fall prize to the little "Shannon" in 15 minutes, were as cheering lights in a dismal view: but they scarcely sufficed to dispel the gloom which hung over most of our naral actions in the last American war, from 1812 to 1815 . Our crews fought brarely, and were bravely led against those who were their equals in every other respect, whilst fired with the double impulse of excited hate and fear of the halter, fighting in superior numbers, wielding better meapons, and flushed with the success attending their contest with an enemy whose force was inferior to them in overy instance in which they were engaged.

Opposing to those of the eneniy, smaller ships, fecbly armed and thinly manned, was the means by which the Government of that day contrived to tarnish tho glory of the British flag in the eyes of a world little informed as to the real merit of the actions which took place.

Let us trust that no future time, should war unhappily arise, may wituess the navy of Great Britain contending on such miserably unequal terms against the enemies of their country, armed with erery adrantage which science, bravery, and nautical skill could cmbark on their side. Yet, we seem to trust, as a nation, to that favouring Providence alone, which has hitherto helped us out of every difficulty, -forgetting, to all appearance and on all occasions, the ancient adage that "the gods help those who help themselves."

The early onslaught of a sudden war will surely test our state of preparation. leaving little time, perchance, for that bringing up of leeway for which the tardy operations of former times gave place, and by which we were enabled through superior sources at hand, as compared with those then at the command of our enemies, to leare off on 
better terms than those on which we had begun. It is obvious that in the present day, howsoever great may be our orn resources, the comparison with those of nther nations is less remarkable than formerly, and I shall presently show that the impulse of a civil war called forth the energies of manufacturing skill in the United States in a manner not to be overlooked, if, indeed, to be equalled in this country, And as in the daily operations of life, the willing giant steam is mado to spare the sinews of thousands of men and tens of thousands of horses in producing the materials in question, so should the very best and fittest weapons be prepared beforchand, and placed in the hands of a nation's warriors in the day of trial, if they are expected to win her cause by their skilful use of them. For, as little could the labour be accomplished without the aid of steam, by which those ships are built and those weapons manufactured, as men can have it in their power to orertake fast ships with slow ones, or to keep on an equality in fighting, when small guns and few of them, are opposed to heavy guns in larger numbers.

None but the very fastest ships, armed with the very best guns that can be put into them at tho time, should be opposed to those, be they weak or be they strong, with whom we may have to contend.

Unity of design and fixity of purpose appear erer wanting under our Parliamentary Government where the intentions of one Administration are rarely those of their successors, and whero spasmodic efforts, ofttimes the consequence of popular panic, are as often misdirected. With great energy we produced in no long time a considerable fleet of screw ships of the line. They still exist in our ports, but they lave lived their little day of usefulness, and are acknowledgedly unfit to cope with any iron-sided ship, however inferior to them in armament and crew.

These have, thereforc, taken the place of the others as the exponents of our naral force; but they would, as a combined fleet, operate under one very great disadvantage against a French force of equally powerful armament.

Omitting, for the sake of argument, the question of whose plates are thickest, or whose guns the best, the French ships are designed so much under ono idea, and with qualities for carrying that idea into effect, that they are ablo to manouvre under stenm with very great precision.

Our own may possibly be classed, in point of speed, in three squadrons, comprising respectively the first six ships in the subjoined list as a 14-knot squadron, the second six as going 13 knots, and the next five going 12 knots ; but even these rarietics of ships differ among themselves, perhaps (excepting the "Defence" and "Resistance"), in respect of sca-going qualities and turning power; while what remain of our 32 iron-clad ships, large and small, complete, or in course of completion, are a miscellaneous collection, no two of which, howerer excellent as individual ships, would recornise each other as sisters.*

- From this statement I must except the "Birkenhead Rams," ("Scorpion," and "Wyrern"), which, as regards hull and engines, aro precisely similar,-W.H. 


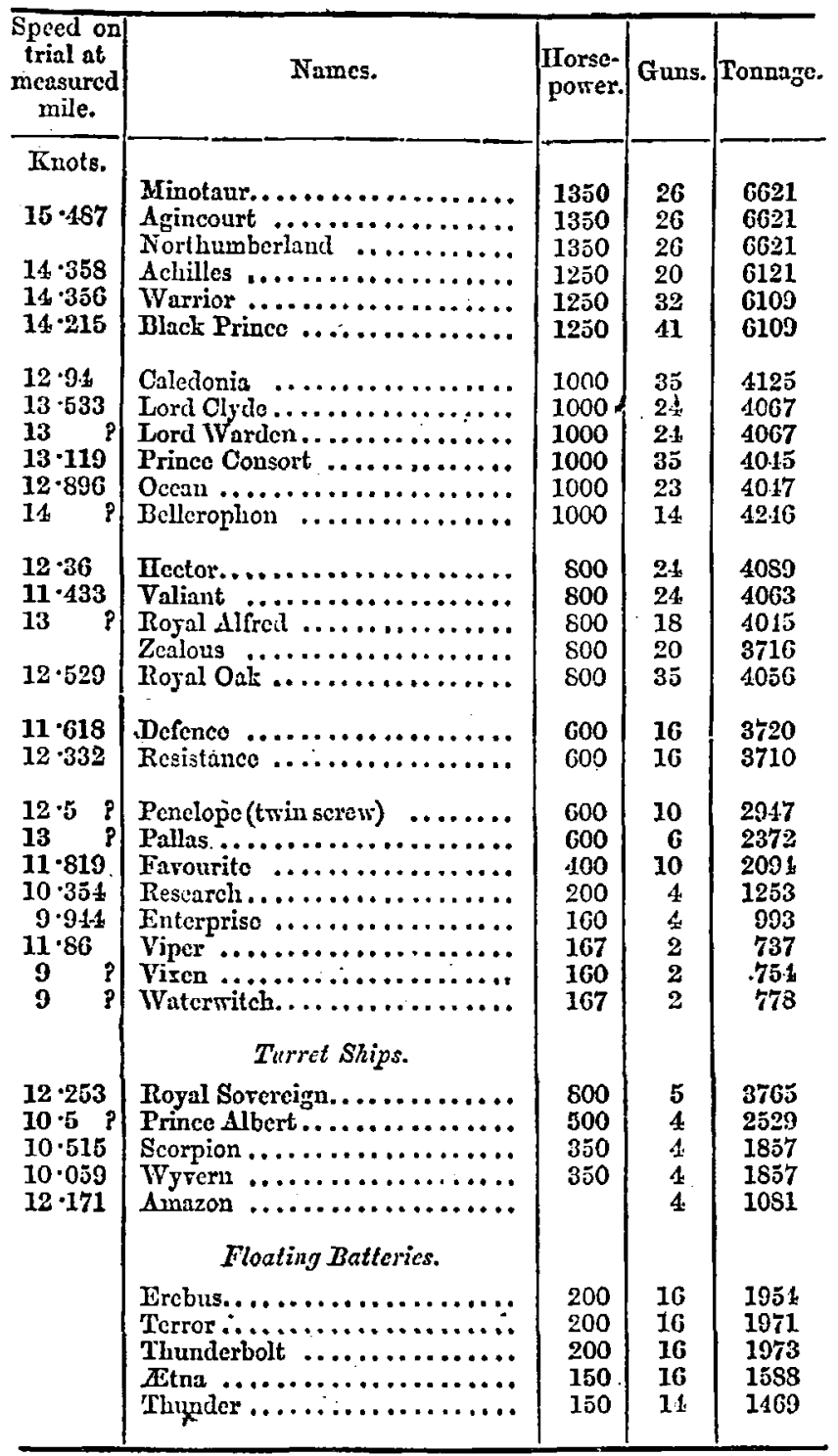

These ships hare not all been tried.-W.II.

In this list of 32 ships (not counting the 5 floating batteries), there are 11 classes in respect of guns, 10 in point of horse.power, and 9 classes of tounage. The grand total of guns is 616; of horse-power, 24,354; and of tons, 120,370; ships, 37.- Wr.I. 
I wish particularly to impress upon the meeting that I have not prepared this statement with the object of finding fault. Our ships may be, and probably are, very superior, talien collectively or otherwisè, to the iron-clad force of any other nation.

I have drawn up this table for the sake of pointing out how one Government may adopt a principle, and work it out with determination of purpose, while that of another nation may accumulate most valuable

\section{Frexcil Tros-clads.}

From "Statesman's Iear Book, 1866."

\begin{tabular}{|c|c|c|c|}
\hline [agenta $\ldots \ldots \ldots \ldots \ldots \ldots \ldots \ldots$ & Guns. & & $\begin{array}{c}\text { IIoree-pow } \\
1000\end{array}$ \\
\hline Solferino $\ldots \ldots \ldots \ldots \ldots \ldots \ldots \ldots \ldots$ & 52 & $\cdots \cdots \cdots$ & $1000\}$ \\
\hline Couronne.................. & 10 & $\ldots \ldots \ldots$ & 3003 \\
\hline Normandic ................ & 36 & $\ldots \ldots$ & 900 \\
\hline Inrincible $\ldots \ldots \ldots \ldots \ldots \ldots$ & 36 & $\ldots \ldots \ldots$ & 000 \\
\hline 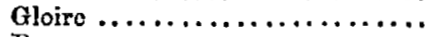 & 36 & $\ldots \ldots \ldots$ & 900 \\
\hline Prorence.................. & 36 & ....... & 900 \\
\hline Iréroina $\ldots \ldots \ldots \ldots \ldots \ldots \ldots \ldots$ & 36 & ........ & 900 \\
\hline Saroio $\ldots \ldots \ldots \ldots \ldots \ldots \ldots \ldots$ & 36 & $\ldots \ldots \ldots$ & 900 \\
\hline Reranche.................. & 36 & ....... & 900 \\
\hline Surreillante.............. & 36 & $\ldots \ldots \ldots$ & 900 \\
\hline Flandre $\ldots \ldots \ldots \ldots \ldots \ldots \ldots$ & 36 & $\ldots \ldots \ldots$ & 900 \\
\hline Guyenne.................. & 36 & $\ldots \ldots \ldots$ & 900 \\
\hline Gauloisc ................. & 36 & $\ldots \ldots \ldots$ & 900 \\
\hline Valeureuso $\ldots \ldots \ldots \ldots \ldots \ldots \ldots \ldots$ & 36 & $\ldots \ldots \ldots$ & 900 \\
\hline MLagnanime................ & 30 & $\ldots \ldots$ & 900 \\
\hline Taureau (cupola, ram) ......... & 1 & $\ldots \ldots \ldots$ & 500 \\
\hline Tormante................. & 16 & $\ldots \ldots \ldots$ & 2257 \\
\hline Dérastation...$\ldots \ldots \ldots \ldots \ldots \ldots$ & 16 & $\ldots \ldots \ldots$ & 225 \\
\hline Lare $\ldots \ldots \ldots \ldots \ldots \ldots \ldots \ldots$ & 16 & $\ldots \ldots \ldots$ & 225 \\
\hline Foudrojante $\ldots \ldots \ldots \ldots \ldots \ldots$ & 16 & $\ldots \ldots$. & 225 \\
\hline Congrèro................... & 16 & ........ & 225 \\
\hline Saigon $\ldots \ldots \ldots \ldots \ldots \ldots \ldots \ldots$ & 14 & $\ldots \ldots \ldots$ & 300 \\
\hline Palestro $\ldots \ldots \ldots \ldots \ldots \ldots \ldots \ldots$ & 14 & $\ldots \ldots \ldots$ & 300 \\
\hline Peiho $\ldots \ldots \ldots \ldots \ldots \ldots \ldots \ldots$ & 14 & ....... & 300 \\
\hline Paixhans $\ldots \ldots \ldots \ldots \ldots \ldots \ldots \ldots$ & 14 & $\ldots \ldots \ldots$ & 300 \\
\hline Protéctrice $\ldots \ldots \ldots \ldots \ldots \ldots \ldots$ & 4 & $\ldots \ldots \ldots$ & $150^{-}$ \\
\hline Impregrable $\ldots \ldots \ldots \ldots \ldots \ldots$ & 4 & ........ & 150 \\
\hline Enibuscade $\ldots \ldots \ldots \ldots \ldots \ldots \ldots$ & 4 & $\ldots \ldots \ldots$ & 150 \\
\hline Rafuge $\ldots \ldots \ldots \ldots \ldots \ldots \ldots \ldots$ & 4 & ....... & 150 \\
\hline Arrogante $\ldots \ldots \ldots \ldots \ldots \ldots \ldots \ldots$ & 4 & ........ & 150 \\
\hline Implacable................ & 4 & ....... & 150 \\
\hline Opinititrc $\ldots \ldots \ldots \ldots \ldots \ldots \ldots$ & 4 & $\ldots \ldots \ldots$ & 150 \\
\hline Ships 32 & 7 & & 18,575 \\
\hline
\end{tabular}

Divisiblo into 5 classes +1 ram.-T.IT.

Thre more frigates and 7 correttes were begun in 1865 .

When the French ships left Spithead for Cherbourg, the signal mas made to procced at 12 knots; and they arrired at their destimation accordingls, witli tho utmost punctuality. How many iron clads out of our 32 could hare obeyed a similar order? We know, from the similarity of the French shirs, that 1t: at lenst of theirs could hare done so. Any improrement of their armament will in like manner affect all their ships of each class in a similar degree.-W.II. 
individualities without arriving at an aggregate of corresponding value. "Perhaps tho classification of our ships in groups may" commend to more favourable consideration the French method of zanocuvring in small squadrons, or pelotons, composed of ships possessing equal speed, and similarity of turning power.

Let all these ships be assembled as a fleet, or cren suppose their distribution to be regulated with such judgment as that corresponding squadrons at least should be complete and kept together, aud let two or three such squadrons assemble for performance of some particular service.

Their variety of speed and of turning power is so great, and so little brought into practice with relation to each other, that they would certainly appear as if brought together for the sake of contrast. Steam tactics, on an extended scale, may be estimated at so many liundred pounds sterling $\mathrm{per}^{-}$diem, and without practice in steam tactics, such squadrons would be in constant danger of collision, or at least of the worst confusion, whenever darkness or thick weather supervened; and the inconvenience of possessing so many dissimilar classes of ships would be seriously felt by all concerned.

The ships in question may be individually rery superior to the French, as I believe they are-better armed, more thickly clad, and provided with much moro ingeniously expensivo contrivances for a variety of uses, necessary or otinerwise.

Tactics may, as regards engaging an enemy, bo rery possibly obsolete. Indeed, I doubt whether the best way of liandling such a force of ships as these, would not be to render the attack as confused as possible, in order to confound the intended measures of the enemy, and so lenve each ship to do the best she could by tackling one of them in the closest fight achievable; but such is not, perhaps, their rightful use.

To succeed in eren this, however, it is needful to have the slips in presence of each other beforehand, in order to avoid delay or disadvantage when an engagement is in prospect. Secondly, for this end certain tactics are undoubtedly required; and for the due execution of technical manceuvres a greater similarity of ships is highlly essential, if not absolutely necessary, especially in narrow sens and winter weather.

I am not suficiently informed to be able to state how many shijs of tho French squadrons manceurre in company, or with what degree of success; but the similarity of many of their ships, and their known power of beeping together at sea, offer suficient contrast with the rariety which prevails among our own, to illustrate how important are unity of design and consistency of purpose in the reconstruction of a navy.

Discussions in the IIouse of Commons and observations in the public press of this country, as well as the derelopment of gun-power; have

- An clementary trial of this system was made under Admiral the lafe Lord Lyons, in 1858, upon a plan drawn up by mo. It was not unattended with suecess during a trial of many days and nights, performing crery rariety of mancuvre, cren though the eight ships varied in size from the " Rojal Albert," 131 , to the "Vigilant," 4 .-W.ir. 
no doubt exercised much influence on the fitful production of our ironclad navy, causing frequent clange of purpose, and modification of design. In France, meanwhile, tho imperial progranme of 1859 has been steadily wrought out in furtherance of that laid down by a deccee of Louis Philippe, and modified only by the introduction of irou-clad ships as a substitute for screr ships of the line, since their successful inauguration before Kinburn in 1855 .

The Napoleonic idea has been to establish an invulnerable cscort for a flect of transports capable of conveying a fully cquipped force of all arms numbering 45,000 or 50,000 men. Its organisation with that object, if not perfect, has at least been for some time complete. The transports now are the dismantled line-of-battle screw-ships of a few Jears since. Other transports of beautiful form, and apparently capable of attaining high speed, are fitted for conveyance of horses and artillery.

Nothing, in short, is wanting but the Napoleonic will, to test the efficiency of such an equipment on the first convenient opportunity; but happily there is no longer any prospect of the experiment being made against a country whose citizens of all classes lave become her defensive force, and with which country the relations of commerce hare.so immensely increased of late.

All other nations besides France are availing themselves largely of the turret system of central armament, the merits of which have been sufficiently set forth through the ability and steadfast perseverance of Captain. Comper Coles, to have at length overcomo all tho objections which prejudice could suggest, or which other considerations could dictate.

Let us trust that the day must be already near at hand when tardy justice shall be done to the value of his invention, and when sea-going turret-ships shall enable us to maintain an iron-clad force in distont seas, having coppered bottorns, steel frames, a shotproof belt and turrets, iron upperworks, and perhaps tripod masts.

Placing: these in the first category as of imperative necessity to secure supremacy on the occan, let us consider in the second place his turret-ships for-Channel service. These nay clearly be almust without masts. Not needing much storage of water or provisions, their space below devoted rather to coals and ammunition, ships for home service may be entrusted to the safe conduct of their engines, while those for foreign stations must have use of masts and sails, with means to feather or to lift their screws.

We may confidently trust the double screns will work themselves into favour sufficiently to overcome the financial scruples of the great engineers, whose pattern slips represent rast capital locked up in models and patterns for every variety of single screw engines adnpted to our ships of war. Once overcome this obstacle, which time alone can accomplish, and which must ever delay a change of system, and even our "Warriors" and "Minotaurs" may be rendered trustworthy for narrow seas and channel service.

Counting then upon these two classes of iron-clad ships as able to carry the heaviest description of guns, viz., the sea-going iron-clads (of tho future) and the turret-ships for home defence, let us turn our 
thoughts to consider the best classes of un-armoured ressels, able either to cut up the commerce of our enemies, or to go forth and cope with such antagonists as now already exist, and will most certainly be employed in ovent of war with the United States, to intercept and destroy our distant trade.

I will cndeavour to place the meeting, as concisely as I can, in pos: session of a rery interesting statement of the steps by which the naval administration of that country was led up to the construction of what represents at present'their definite idea.

The document from which I am about to read extracts, is a somewhat lengthy letter from Mr. Donald MrcKay, tho great ship-builder, of Boston, addressed to a local newspaper, the Boston Advertiser, and printed in its number of 29 th Uctober, $186 t$.

Referring to former writings of his own, in which he had related what had come under his observation in recent risits to the naval dockyards of England and France, Mr. MrKay writes: "I saw that "those powers respected nothing but force, and knew that if wo " desired to prevent foreign intervention in our affairs, our navy mast " be largely increased."

I apprehend that these viess, formed prior to the outbreak of the civil war in America, may, mutatis mutandis, be now equally entertained in other countries with reference to the United States.

Let us see then what are tho powers of naval development displayed in that great country:-

"At the breaking out of the rebellion (the words are those of "Mr. D. MrKay) the navy consisted of the following steamers. The "'screw-frigates ' Merrimack,' ' Wabash,' 'Minnesota,' and ' 'blorado,' " of about 3,350 tons each; of the large screw-sloop 'Niagara', of " 4, 582 tons; of the first-class serew-sloops 'Richmond,' 'Brooklyn,' " 'San Jacinto,' 'IIartford,' 'Pensacola,' and 'Lancaster,' of about "2,000 tons each; of the 6econd-class sloops ' Pawnce,' 'Iroquois,' " ' Wyoming;' 'Mohican,' and 'Dacotah,' of about 1,070 tous each ; of "the third-class sloops 'Narragansett ' and 'Seminole,' of about 850 "tons each ; of the first-class paddle-whecl sloops 'Susquehanna' and "' 'Powhattan,' of about 2,430 tons; the 'Mississippi,' of 1,692, and "' 'Saranac,' of 1,446 tons; and of the small paddlc-wheel steamers "' 'Michigan,' 'Saginaw,' and 'Spitfire,' of about 470 tons each; " making a total of 26 steamers and 49,700 tons."

It may be well to state that the laws of American tonnage represent a larger burthen than is estimated by the present rule in this country; in other words, 100 tons British are equal to more than 100 tons American. .

Mr. MrKay next tells the speed of these ships, which I beg leare to read, at the risk of being tedious, and without vouching for the ratio between British and American nautical miles. It may possibly approach that which exists here between ships at sea and those on trial at the measured mile; nevertheless, the performance quoted does not bear the stamp of improbability. It is as follows :-

" 'Niagara,' 10.9; 'Merrimack,' 'Wabash,' 'Minnesota,' 'Roanoke,' " and 'Colorado,' 9 ; 'Broollyn,' 9.2 ; 'San Jacinto,' 8.8; 'Hartford" 
" and 'Lancaster,' 955; 'Richmond,' 7-5; ' Pawnee,' 8 ; ' Iroquois,' “ 'Wyoming,' 'Mohican,' and 'Dacotal,' 11- 7 ; 'Narragansett' and " 'Seminolê,' 8; 'Susquehanna' and 'Saginan,' 9; 'Wraterwitch,' 9; " 'Michigan,' 10.5. The 'Pensacola' proved a total failure, and the " machinery had to be remored."

This statement of speed is very modest, and justifies a reliance on the others made by Mr. MeKay. The last fact mentioned also shows that our transatlantic friçnds no more enjoy inmunity from error than do we ourselves.

Let us now learn from him what means were at their command, and what results those means achicred. Me says:-

"The means at the command of the Administration for building a " steam nary were about 2 dozen inachine shops, great and small, dis" tributed from Maine to Maryland, many of them very small, and "without the tools, workmen, or skill requisite for the production of " marine machinery. The first-class shops did not exceed eight in " number. But the entire force of these shops could not be commanded " by the Navy Department for" construction of new maclinery. There " were the enormous quantity of repairs to the merchant steamers of the " country to be done, and new construction to be made for that ser"vice. The WVar Department also drew largely on their resources for " transport steamers, while the locomotive and tool-maling shops found " it utterly impossible to meet the demand upon them. Neither were " there sufficient raw materials in the country for the large and sudden " demand. IIundreds of steamers, hundreds of locomotives, shops" full of tools, tens of thousands of tons of metal were called for " instantly, and there was nothing on hand to meet the call. War "steamers cannot be built in a day. Inexperienced labour cannot be " converted into skilled mechanics in a day, the prices of machinery " rose immensely, the pay of the mechanics and the cost of material "reached a point far above what they were worth, except from the "factitious cause of the suddemness of the demand.

"The result was felt in the poor materials and poorer workmanship " with which the machinery was made. Any kind of material and the " most unskilled labour had to be brought into use, and all this time "the amount of even that labour was constantly diminishing by the " absorption of men into the military service."

IIero we may learn a lesson of the pcnalty incurred by a state of unpreparedness. By continuing the story we shall sce what can be done with comparatively small resources when strong will gives proper impulse and direction to the use of resources horrsoever small.

"In this pressing emergency the Department did all that could possibly " be done. It purchased every merchant sieamer that could be con"verted into a blockiding vessel or a war cruizer, and the nav $y$ at this " moment contains every merchant steamer of any size or excellence "that has been buill in this country. It set at work every steam" engine factory in the land that could produce marine machinery. It " considered all plans offered for armouring ressels, and tried many. It " instituted experiments in machinery, in ordnance, and in armour"platiug. It covered the Mississippi and its tributary waters with an 
"immense inland fleet, many of which were armoured, and which "sweeping the rebels from those waters, have been an indispensable " element to our holding the whole interior of the country, as it gires " th the exclusive command of its water highways. It lined the "Atlantic coast with such a blockading flect as the world never wit" nessed before, and has practically closed the rebellious district to the " world, the few vessels which succeed in running the blockado being " too small to carry cargo sufficient to gire any aid of consequence. "The rebels have not been able to import even drugs enough to "supply the Medical Dêpartment of its army."

Noiv, these words are not mere "tall talk," they conrey a record of facts important to ourselves, and against which we ought not to oppose a foolish self-sufficiency and ill-grounded self-confidence.

The results achieved in the way of ship-building are thus recorded by Mr. McKay:- "The first ressels constructed by the Department "were 23 screw gun-boats of $50 \pm$ tons each, with a speed of 10 knots " and a draft of 9 feet. They were intended especially for blockading " the mouths of the smaller rivers. 'The 'Iroquois,' 'Wyoming,' and " 'Mohican' were next cluplicated, the former twice, in the 'Oneida,' “" 'Kearsage,' 'Wachusett,' and 'Tuscarora.' The reason for exactly " duplicating them was the fact that as the drawings and patterns were " still in the hands of the original builders, the machinery could be " obtained much quicker, and time was the element of most importance." How wise this course pursued by tho Americans, and how different from a system, or want of system, which continues perpetually adding cvery varicty of ships to a navy in which scarcely two agree in any one particular.

"These vessels were followed by the paddle-wheel guuboats "s 'Maratanza,' 'Mahaska,' 'Sebago,' 'Octarora,' 'Sonoma,' 'Cone" maugh,' 'Tioga,' 'Genesce,' ' Mliami,' ' Paul Jones,' ' Port Royal,' and " 'Cimarron,' twelve in number, of about 850 tons each, and having "a maximum speed of 11 lnots per hour. To these succeeded 27 " others of the same type, but larger and faster, being of 974.tons "burthen, and having a maximum speed of 14.5 lnots per hour.

" 'Their names are the 'Eutaw, 'Sassacuss,' ' Wateree,' 'Patuxet,' " 'Tallapoosa,' 'Winooska,' 'Mackinau,' 'Shamrock,' 'Tallihoma,' " ' 'Tacony,' 'Tosco,' 'Agawam,' ' Pontoosac,' 'Massasoit,' ' Osceola,' " 'Mattabesett,' 'Chicliopee,' 'Ascutney,' 'Otsego,' 'MTetacomet,' " 'Chenango,' 'Lenapee,' 'Nendota,' 'Mingoe,' : WYalusing,' 'Pon" tiac,' and 'Peoria." "

"Other seven of this class, but still larger and built of iron, have " been lately added, viz., the 'Winnessee,' 'Ashuclot,' 'Mluscoota,' " 'Suwannee,' 'Shamokin,' 'MIoliongo,' and 'Mlonocacy,' all of 1,030 "tons. These paddle-wheel gun-boats have the light draft of 8 feet, "and carry enormous batteries. They were built for special service in "the narrow and tortuous chansels of the shallow sounds and estuaries " of the southern coasts. For these localities where turning was in"possible, it was necessary they should be double-bowed, i.e., con"structed with both ends alike, and that their machinery should be " equally well adapted for going forward or back. 
"In the antumn of 1861 the Department commenced the coustruction " of ten second-class screw sloops of war, of about 1,350 tons. They " are the 'Ticonderoga,' 'Lackawamna,' 'Shenandoah,' 'Monongahela,' " 'Ossipee,' 'Juniata,' 'Sacramento,' 'Adirondack,' 'Housatonie,' and " 'Canandaïgua.' 'They have a maximum speed of 12.25 knots, carry a " large armament, and are efficient ocean cruisers.

"' There is now in progress of construction the 'Chattanooga,' of " 3,000 tons, building for the Department by ontside parties; also the " 'Idaho,' of similar tonnage, and by other outside parties; while the "Department is itself constructing the 'Mladawaska,' 'Wampanoag;' " ' Neshaming,' ' $\Delta$ mmonoosuc,' and 'Pompanoosuc.'

"These vessels are of wood, about 3,000 tons, and intended to have " a speed of 16 linots an hour. 'They will carry immense batteries, be " full rigged, and will doubtless prove the fastest and most formidable " ocean eruizers ever built by any power.

"There are also in course of building by the Department twenty "first-class wooden screw-steamers, of 2,200 tons each, to have a "speed of 13 knots, carry enormous batteries, and be full-rigged for "ocean cruisers. They will soon bo completed." ('This was more than a year ago, remember.) "They are named the 'Antietam,' " 'Arapaho,' 'Guerrière' 'Hassalo,' 'Illinois,' 'Jara,' 'Keosanqua,' “ 'Keywadin,' 'Manitou,' 'Minnetonka,' 'M Mosholu,' 'Ontario,' 'Pis" cataqua,' 'Pushmatala,' 'Talgayuta,' 'Wanaloset,' 'Watanga,' " ' Willamette,' 'Contoocook,' and 'MIondanim.'

"While these ressels are building, there have been completed the " 'Nipsic,' 'Shawmut,' 'Nyack,' 'Pequot,' 'Mraumee,' 'Kansas,' " 'Yantic,' and 'Saco,' all screw vessels of 593 tons cach. The " machinery is from designs of various partics, building to compete "with the Department. The first three liaving the Department's ma" chinery, have been thoroughly tried, and can maintain a speed of "11.j knots.

"There are now nearly completed the wooden iron-clad coast " steamers 'Tonawanda,' 'Miantonomoh,' 'A gamenticus,' and 'Mon" adnock,' of 1,564 tons, drawing 12 feet ' of water, and having two "turrets ench, carrying two 15-inch guns. The 'Monadnock' has " been tried, and is found capablo of achieving a maximum speed of " 11 knots.

"There are also in process of construction four other iron-clads of "the same type, but larger, and to be faster. They are the 'Kala"' mazoo,' 'Passaconaway,' 'Quinsigamond,' and 'Shackamaxon,' cach " of 3,200 tons.

"The Department has also constructed 74 wooden and iron-clad ves" scls of the 'Monitor' type, with an aggregate tonnage of 78,000 vons. "There are'now in the navy, in active service, 558 steamers, with " an aggregate tonnage of 408,000 tons, against the original 26 steamers " and 49,700 tons with which the war commenced.

"Of this number, 200 steamers, with an aggregate of 241,000 , have " been built by the Department. In no country, and with such limited " means and under such difficult circumstances, has there over been" put " afloat, in the same time, such an immense naval armament. . . . 
"The naval administration has done all which any naval administra" tion could do in such a war.

"facts, which can easily be verified by reference to official documents, " and which I deem justly due to our present Nary Department. . . . "Certainly it cannot be said that in the time of trial the Navy Depart" ment has been found wanting."

Most fortunate the Administration which can eam for itself such unqualified praise-and fortunate above most other nations that which can with justice accord it. The Presidential Message of Iast month states the number of guns in the American navy to have amounted to 3,000 , while their crews numbered 50,000 men.

A few remarks upon the foregoing extracts may not be out of place. First, with regard to the much-vaunted "MIonitors;" they are entirely out of favour. I cannot say whether the mode of constructing the turrets, wholly different from those of Captain.Goles, occasioned disappointments, or whether they are considered to be superseded by torpedoes as a means of defending the coast. Certain of them have been converted into vessels for torpedo service, and the remainder are laid aside as not required for any present purpose. 'The "MIonadnock," as an exception, has been sent round to California.

The verdict against them from some of the admirals was to the effect that the men who had fought in them conld never after be kept from under cover when engaged, and this applied to all the iron-clads. That of the officers employed in them was that they were hell.

Secondly, Mr. Mickny speaks raguely of "cnormous batteries," which may mean anything; but the 15-inch guns afterwards specified are a familiar fact, whilo wo hear of 20 -inch guns in course of construction.

I am not about to discuss questions of initial velocity or penetration, but will merely observe that a 15 -knot steamer, armed with 15 -inch guns, and able with superior speed to range alongside at any period of the 24 hours, would bo a very formidable antagonist to the most heavily armoured vessel, mounting the most perfectly rifled guns of the comparatively small calibre employed by us, and possessing the best speed yet realized by any but two or three of our ships of war.

From subsequent information, I learn that the dimensions of some of these ships nre as follows:-

"Ammonoosuc" Class.

3,713 tons, 17 to 19 guns. 335 feet long, by $48^{\prime} 2^{\prime \prime}$ beam.

To steam 15 knots and upwards.

"Guerrière" Clazs.

3,177 tons, 21 guns.

313 feet long by 46 broad.

To steam 15 knots. 


\author{
"Idaho" Class (tmin ecrers). \\ 2,638 tons, 8 guns. \\ 305 feet long by 14 broad.
}

To steam 15 lnots.

There are various other classes, some of which fall short of the original intentions of their constructors, but which may nevertheless prove most valuable cruizers. Their general proportion of length to breadth appears to be about 7 to 1 .

I would leave out of the question the use of the stem on the side of the faster ship, and assume that her superior speed will always enable her to avoid that of her iron-clad opponent.

The same superiority will enable her to keep beyond the range of rifed guns by day, without losing the power of closing again at nightfall, when the long range and precision of the rifled guns would become of too uncertain effect to be reckoned as an advantage. Approaching cnd on, and offering comparatively but a small mark, she would find opportunity to range alongside and delirer such a discharge as would probably sink the antagonist, whether armour-plated of not; for, with guns depressed and fired only when almost touching, the 15-inch shot would probably go out through the bottom, learing but little chance of safety. Such, it appears to me, would be the tactics to be pursued by a single ship possessing a marked superiority in spced and in calibre of guns. The use of iron under-decks and of an iron inner skin will probably keep within control the incendiary effects of shells exploding between the decks; and.where destruction of the ship is the object in view, round shot, of large dimensions seem to afford to a very fast ship the best means of achieving that result. The reduced number of guns, lenving available a larger proportion of the crew than formerly for the other dutics of the ship, especially for extinction of fire, would point to outward injury by shot as of more serious importance in an action hereafter than the destruction of life or confusion of the crew likely to be occasioned by the explosion of shells.

This argument applies more especially against iron-clad ships whose armour would derive more injury as to sea-going qualities from violent and repented concussion than from perforation. The iroin-clid ship, with plates buckled and bolts distorted, would be left in worse case than her un-armoured mooden opponent with shot-holes plugged and fire extinguished.

Let me not be supposed to argue against a supply of rifled guns to erery ship for special uses. Yet, I liold strongly to the bolief that very great advantage will attach to the uso of spherical shot in future naval engagements as in former ones, whether employed against ships with armour or those wilhout. And while the Americans are increasing yet more the calibre of their smooth-bore guns, it is hardly to be supposed they will allow their largest ocean cruizers to be unprovided with whatever class of guns may be their best from time to time.

It is, morcover, contemplated, if not already arranged, that all ships 
in the American navy should be provided with apparatus for the use of torpedoes.

Whether they may ever succeed at sea in landing them on the decks or placing them under the bows of vessels possessing inferior speed, is a problem as yet a long way short of solution; supposing for argument that it could be done, the explosion by means of electricity would ensue immediately, beyond hope of cutting the wire or of ejecting the intruder. The powder for this purpose would be in waterproof bags, to be swung out by whips from the yard-arms.

Whether this mode of putting salt on tho bird's tail proro practicable or otherwise at sea, no doubt can exist that an unscrupulous neighbour in a neutral port, provided with these insidious means of destruction, would be a very dangerous companion; and some precautionary device to mect this danger appears to have become very necessary, for we hare scen how public applause has greeted the return of ofticers whose personal. ambition or false zeal had led them to commit the grossest outrage on neutrality.

It needs little consideration to accept the fact that ressels such as hare been described and of which the full details are in this country, must, while unmatched in speed and sen-going qualities, practically command not only the seas full of our floating wealth, hut must also threaten the possession or the security of our colonies in their present undefended state.

Our North American dependencies are too conreniently placed as an ever-ready means of annoyance, for the United States do really aim at their acquisition. For that reason they may possibly remain $a$ practical pledge of peace between the two conntries, so long as they continue under the British Crown. They will assuredly at the same time continue to be a perpetual source of threatened annoyance, and of consequent irritation, until declared independent.

With regard, however, to the other colonies of Great Britain, in general, - to assume that foreign nations are deceived by the nominal garrisons and tumble-down batteries in many of our distant possessions orer sea, is to behare like the silly bird which buries its head in the sand or mud to seek imaginary security from its foes, or like a child which shuts its cyes and fancies itself unseen by others.

All nations must be aware that in the extended dominions of this country there are hundreds of points at which contributions to any extent could be levied with the same facility and success which attended the buccaneers of old on the Spanish Main.

Nor is it to be supposed that cruizers such as I have just described, would limit their depredations to such ships as they might mect at sea. The colonies and forcign possessions of Great Britain would furnish them with supplies of all descriptions, with abundant plunder, and with a fictitious lind of glory, cheaply acquired, to our great shame and at our cxpense. For the United States to send forth such cruizers, counting upon such supplies, would be a much more popular and efficacious mode of warfare than to break their heads against the stone forts and iron shields which are being made to line our shores; 
still more so than to test their strength against a defensivo fleet of iron-clad ships backed by a system of torpedoes.

I will now beg leave to read what many here present may have already seen in the pullic journals - an extract from a letter of the Prince de Joinrille-no mean authority on naval affairs. The letter is dated 28th April, 1865, and appeared in the English papers in October.

Addressing an American, the Prince says:-

"You must be proud, Sir, of the doings of your navy. With the " brilliant exploit of Conmodore Winslow, has the tide of victory "turned with you. The achievements of MIobile Bay are without " parallel, and reflect the greatest honour on your flag. Ail naval " men pay a just tribute of admiration to Admiral Farragut, and his " brother" officers and men. This war will leare your navy in $a$ "very enlicient state, and with a feeling of confidence in itself which " is one-half of success.

"Not so in European navies.

"Ours is tired and disgusted by the odions service of transports im" posed upon it. The British Hary after a long period of inaction, and "furnished with ships and men it has no confidence in, is not what it "was formerly. Both navies continue to build sen-going broadside " iron-clads of immense size and cost, but the policy of building such " expensive ships when they may be so easily sunk by a miscrable " torpedo is much discussed, and the tide is coming to small iron"clads with two or four guns 'Monitor' fashion.

"For long cruises, fast iron-clad sloops, 'Alabama,' or rather " 'Florida' fashion, seem also to be most appropriate. Upon all these "points you have the lead.

"Where ererybody is still belind, is in gunnery. The best English "gun is the 300-pounder smooth-bore, muzzle-loader, Armstrong gun, " built on the coil principle and able to throw its shot with a very " heavy charge of powder. The Royal Navy has no good gun of " lieary calilire, but I think MIr. Blakely can turn out some very " efficient ones. The French hare no heary guns, smooth-bore or " rifles, and have not jet succeeded to experiment successfully on any "one. T'he best gun we have in use is a breech-loading rifle gun, "throwing a 60-1b. shpt with a low charge. That gun works well, "and is very accurate, but of no uso against iron-clads.

"The Emperor is trying a gum of his invention, rifled, and made of " steel inside, and brass outside. I have no faith in it.

"It is from the United States that we expect the production of the " largo rifled gun for sen-serrice, as soon as your clever workmen "slall liave turned their minds to the production of built-up guns of " steel or wrought-iron.

"That heavy gun is much ranted, since the battle of Mobile has so " much shaken the confidence in the employment of rams."

The following significant paragraph appeared in the papers, curiously enough, the following morning. It forms part of MIr. Adams? letter to Earl kussell on the claims against the "Alabama," \&c.

"Further than this, I might only suggest to your Lordship to con" sider vrhich of the nations of the world presents in every sea around 
" the globe the most tempting prizes, in an erent no friend would " more deplore than myself, of its being again as it has so often been " heretofore, doomed to be aflicted by the calamities of a war."

The practical lesson to be derived from these considerations seams to me to be, in tho first place, that our nation depending so largely for its means of existence and prosperity, on the supplies derived from abroad should cstablish as rapidly as possible a defensive naval force in every colony capable of naintaining one, nccording to the provisions of an Act of Parliament passed in A pril last, " to make better Provision for the Naval Defence of the Colonies," a title indeed, which in itsclf admits the necessity for what I am endeavouring to recommend, although it is little likely to be carried into full effect so long as a semblance of defence from home is maintained.

Secondly : reserve a sufficient number of our existing iron-clads for home defence, rendering them in all respects as efficient as possible for that specific purpose, and adding to their number a great nany turret ships, almost confining our future iron-clads to that form of armament; and

Thirdly, to cnlarge the idea of "improved Alabamas," as the class of small corvettes now in course of construction has been too truly termed, in favour of vessels in erery respect equal, and in point of numbers far superior to the magnificent class of ships constructed in America, giving them if possible central armament in shotproof cupolas such as have been adopted in the Italian turret-shị "l'Affondatore."

The existing engines of our line-of-battle ships might possibly be made available for propelling such ships at a very high speed." Their wooden hulls could be quickly put together, as evidenced in the "Lord Warden," of 4,000 tons; partially armoured in course of building, which was laid down in November or December, and launched the following August.

Give them steol frames, beams, and decks, and they would be still more quickly constructed and infinitely stronger and more durable.

Such ships would not only protect our vital interests in distant seas, but would maintain the honour of our flag against all enemies whatsoever.

They would moreover, in time of peace, restore the declining spirit of seamanship in our navy, and being armed with but a small number of the heaviest guns, these might always be maintained of the best and most approred description.

To imitate the Americans still further, instead of retaining these particular ships on certain'stations, spending the greater part of their time in the hurtful inactivity of forcign ports or at the various headquarters of the different admirals' commands, let their cruize extend to ercry sea in turn where an admiral's flag is liept flying.

* Our linc-of-baltle ships and frigates hare a proportion of length to breadth as 15 , or 5 to 1 , while we hare scen that the Americans build on a ratio of 7 to 1 . This change of proportion, with the improred form of a rectangular midslip section and rery fine extremitis, would cuablo the eame engines to propel at a much greater specd.-T. II.

vGL. $x$. 
By this means eacl station would be provided at all times with a certain number of fast ships for any special occasion which might arise, while the ships themselres would come in turn under the command and inspection of every Commander-in-Chief.

A grenter uniformity of system would thence ensue among both admirals and ships; certain specified rendezrous at particular times woull keep the morements of the ships sufficiently under the control of Government, and ensure communication throughout the flect.

The cruize of each such ship round the world, when not detained by special emergency, would be her period of commission. Its duration could be perfectly controlled by the sereral admirals under whose command she passed, while the functions of the admirals themselves, in taking care that every place of importance should be duly visited from time to time, would partake more of independent reality and less of the system of centralisation which, for good or for ovil (and it is much to be feared that the latter condition predominates), has been in a manner forced upon every branch of the Administration through tho enlarged use of the telegraph and the increased facility of communication which lave arisen in the last ten or twelve years.: I may mention two circumstances in illustration of this tendency to centralize, as bearing immediately on the subject in hand.

$A$ bout tlie year 1858, application was made by some of the $\Lambda$ ustralian Gorernments to purchase, at a fancy price, some of the old teak block-ships fitted with screws for const defence.

Most of the ships have since been otherwise disposed of ; but the offer was then refused, as tending to separate the colonics from the Imperial Government.

In the year 1865, howerer, we find a Bill passed, entitled "The Colonial Naval Defence Act," giving power for colonics to provide vessels and raise men, and to commission officers, \&c., tho clauses of which Act may shortly be stated as follows:-

1st. lower for colonies to provide vessels and raise men and commission officer:s, \&c.

2nd. Volunteers to form part of Royal Naval Reserve.

3rd. Power to Admiralty to issue special commissions.

4th. Placing of colonial ressel with men and officers at IIer Majesty's disposal.

5th. As to services of volunteers and officers in nary.

Gth. Delegation of Admiralty powers to naval officer.

7th. Not to imposo charge on imperial revenues, \&c:

sth. Not to affect powers vested in colonies.

I hare been unable to learn in what degreo it is contemplated to carry the provisions of that Act of Parliament into effect, beyond enrolment of volunteers for the Royal Naval leserve, with a view to their employment in the Royal Nary, thus drawing a supply of scamen from the very source for the protection of which the Bill is enacted.

* It would also be a great.improrement if on all foreign statioi $s$ our ships were licpt in more constant morcment under sail, instead of remaining, as occasionally they do, for many months together in the same port, producing many inconreniences both to indiriduals, to discipline, and to the public serrice in other respects.-W. H. 
For all other purposes this $A$ ct appears consigned to the same limbo with the vote for the establishment of Naval Barrachs, and in which lay for many years, the Act for establishment of Naral Prisons.

The other measure to which I referred was the abolition of the Indian Navy-a swall force, but efficient for the purposes requircd of it, and comprising a body of oflicers familiar with those seas in which, as a result of experience, the ships were well adapted to serve.

These two measures on the part of Iler Majesty's Gorernment, which it would bo scarcely becoming on my part furtlicr to discuss, nevertheless bear strongly on the question of separate Colonial Defence, which intimately affects both the services and the distribution of our ships, and consequently the mature of the ships thenselves.

Let the full purpose of the Colonial Defence $\Lambda$ ct be carried into effect, establish dockyards in the distant colonies, with suitable, and well-protected depôts of coal, and let the colonies maintain and beğin to use them, in preparation for their separate existence in time to come, and thereby provide for the refit and repair of the slips of the lioyal Navy in case of an extended naval war. It can hardly be said with truth that the colonies are attached to the mother country by such questions as affect the declining days of worn-out block-ships, nor, in the present day, would a warlike conflict with the mother country be the manne: in which their separation should be effected; but the transfer of some of the colonies to other lands might well arise in time of war, out of their present defenceless state.

It happened on more than one occasion (so at least according to the nowspaper account), that small cruizers of the Northern or Southern States during the late war, arrived in ports where no power existed able to compel their departure at the expiration of the allotted time.

The colonies should at least bo made capable of resisting such casual cruizers without delay; and, by degrees, bo rendered so independent as to leave our ships available for their own definite uso as cruizing ships of war.

Iet the ships constructed to cruize upon the ligh scas be of a character to maintain the honour of our flag against all cnemies; for this purpuse let them be in all respects at least equal, individually, to any possible enemies, while numerically more powerful; and lastly, though we may hope and trust that the United States of America mas not agrain stand in that relation to us, let us remember that heretofore we suffered more at their hands than by all other enemies combined against us, and considering them the mest formidable foe with whom we may be brought into conflict, let us construct on the principle and pattern of theirs, a far larger number of similarly serviceable ships than they are likely to require or to possess.

The adoption of such a type and class of ships rould not be without an incidental conscquenco which is professionally of the very first importance.

Together witl a rerival of seamanship we should obtain a considerable increase in the number of bonâfide scnmen.

The idea las taken hold of many minds, and I confess to having myself shared the opinion, that the introduction of iron-clad ships would c 2 
very much reduce our navy, restricting the necessary number of both officers and men, and confining within comparatively narrow limits the much-to-be-desired forco which is expressed by anticipation in tho torm "Standing Nary."

Rightly or wrongly, the Government appears to lave adopted that view of the case, and has acted upon it in all but the final object to which a reduction of number would especinlly have seemed to direct, and, limiting the theory of a permanent naval establishment to the existing system of engaging the men for ten years, and of supplying boys through the training-ships exclusirely, a great prominence has been giren to the two elements of reserve, viz., the body of $7,000 \mathrm{men}$ in the Coast Guard, and whatever number may be forthcoming, wher required, from among those enrolled in the Royal Naval Reservo.

The present system of manning the uavy, as must be known to most persons present, is a very excellent one as a theory (but one which, I think I shall show, requires to be much extended in practice), viz., that of receiving scarcely any men, and those under peculiar circumstances, otherwise than by the advancement of boys as they grow up, who begin their eareer in the training-ships between the ages of $14 \frac{1}{2}$ and 16 years.

Such boys undergo an excellent preparation in ships devoted to that use, under the command of officers, especially selected on account of their qualifications. The navy affords so good an opening for respectable lads, that any number of them could bo obtained from rural districts, brought up in the parish schools or workhouses, strong and healthy. Instead of which I shall presently show that only a sufficient number of boys are allowed to pass through the training-ships to supply one-half of the annual waste.

Leaving aside the quality of the article, and dealing only with the numerical part of the question, about 2,000 boys pass annually through the training-ships, to supply an annual deficiency of between 4,000 and $5,000 \mathrm{men}$, discharged from various causes, including disense and death.

This numerical loss, though becoming less in proportion crery year, is nerertheless continued year by ycar through the pursuance of a system which, during tho past ten years, has diminished the number of seamen-I speak of actual sailors-in- Mrer Majesty's Nayy, by no ferver than 20,000 men. Now, although this loss of men is said to be compensated by the two-fold Reserve of Coast Guard and enroll 1 men from the merchant sersice and elsewhere, it could not be continued without very great inconvenience, were the navy more actively employed than it is at present.

Not niany years since, a reservo of seamen was kept in hand at each of the naval ports, in readiness to embark on any emergency.

By this means the great delay in manning newly comnissioned ships was avoided, and the system being still in force when the affair of the "Trent" arose, ships were despatched in a very short time, through the zealous cxertions of the officers in command (e.g., the "Oriando," 50 -gun frigate put to sea in six days from the appointment of her Captain, Francis Scott, C.B.), whereby great credit accrued to the naval administration for its activity and forethought. 
Should a similar cmergency arise at this time, I believo the Coast Guard would have to be embarked, for want of any availablo reservo in the ports.

Should the Royal Naval Reserve be required, it is supposed that about 8,000 men could bo at once found available.

Still, neither the Coast Guard-rood men though they be-nor the various qualities of men who receive $f 6$ a-year for passing through a periodical training in the use of guns and arms, would supply the deficiency of real actire seamen.

It is true that the quondam seamen, who have entirely abandoned the sen and followed other trades, are being eliminated from the Reserre as fast as practicalie, and their place supplied by men more or less accustomed to the sea, and able to satisfy the official authorities who receive them into the Reserve, that they actually possess a stipulated amount of scaman-like skill. Nevertheless, the qualifications of an able seaman in the merchant service are wholly undefined by law, and many more such men aro required to supply the ready activity and the skilful qualities of a far smaller number of disciplined seamen, trained from their youth upwards in the Royal Navy.

Information from various sources shows that the greatly increasing demand for seamen in various quarters of the globe-which has truly been said to have "groutn larger" within the last few years-will continue more and more to drain our merchant service of men, whom the proffered advantoges of the Reserve will searcely suffice to retain available for the sudden service that may be required of them. I believe ic to be a common practice at Liverpool for emigrnnt ships to evade the law which requires them to carry a crew numerically greater than those of ships otherwise employed, by inserting the names if emigrants on the ships' papers instead of the additional seamen, the persons thus inscribed signing the articles of agrecment, and receiving pay at the rate of $6 d$. or $1 s$. per month.

The provisions of the Act of Parliament, if not thus evaded, would demand about 3,000 seamen annually, who would be discharged on arrival at their port of destination, and of whom tho majority would enter upon some more profitable rocation.

The reduction in the number of available seamen from these and other causes has led to evasion of the law in the manner described, through the difficulty in obtaining them.

An official return from the Registrar-General of Seamen, completed to 1863 , showed that during the previous five years, while the ships, the tonnage and the total number of men in the merchant service had increased respectively as 4,9 , and 4 per cent., the absolute decrzase in the sailor class during the same period had been as follows :-

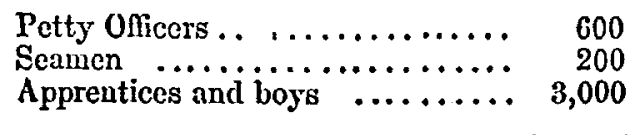


the country out of the merchant service alone in 5 jears, being at the rate of 65 per month.

This loss of scamen, added to that which occurs in the Royal Navy, is a very serious matter in a country whose existence may be truly said to depend on the sea which surrounds it.

The increased number of ships during those five years demanded an increase of crew to the amount of 4 per cent., while the tonnage increased in the same period 9 per cent. This increase was chiefly in steamers, for wo find the increase of the men to consist of 600 enginccrs and 1,700 fircmen.

Among the sailors, howover, wo find another kind of increase upon which wo cannot congratulate ourselves as a maritimo nation, viz., that of foreign seamen added to the merchant service to the amount of 7,500 in the same five years, which represents a daily entry of four foreigners against a daily loss of two British geamen.

On mentioning this fact to a merchant ship-master of great experience, I was met by the reply that ho preferred Swedes, Norwegians, and other foreigners, to many of the British seamen obtainable by merchant ships in the present day.

ducther experienced ship-master observed to me on tho same subject, " the navy was formerly glad to get what men it conld; but now "it has all the best men, and we are obliged to put up with what we "can get."

Surely if this be the character of the supply on which wo depend for our Reserve, it is not only important that an abundance of seamen should be trained expressly for the navy, of whom many would join tho lieserve after the completion of their term of engagement in the navy; but also that wo should employ them afloat in such ships as would keep them in the constant exerciso of seaman-like qualities, by which alone can their superiority be maintained.

I will read a passage from a letter addressed to IIis Grace the Duke of Somerset as First Lord of the Admiralty, by the present Controller-General of the Coast (iuard, and by one of the members now representing Liverpool in Parlinment, who is also chairman of the Local Marine Board at that port.

Those gentlemen viewed tho loss of nautical skill from this country in so serious a light, that they published their letter as "On the national "dargers which result from the great deterioration in tho scamen of " the mercantile marine."

The writers evidently gave much consideration to tho subject, and must havo been deeply impressed with its importance, if we may judge by the amount of pains they lestowed on tho claboration of their letter.

Indecd, to find considerations of national honour on the sea, to say nothing of national security at lome, made subordinate to the fiscal questions of the day, but little encourages any attempts to press upon public considerntion the importance of recruiting our naval force from the condition into which it has settled down, and is still, year by year, settling lower.

Commodore Ryder and Mr. Graves, in their pamphlet, dwell upon 
the necessity for seamen to possess certain qualities which they describo as follows:-

"(1.) A firm footing in all weathers, at all times, by day or by night, "aloft or in boats, which is essential to accurate practice with great "guns or small arms.

"(2.) That bodily activity which results from constant exercise aloft " in all weathers.

"These two qualities combined make our seamen fearless. and irre" sistible boarders. Whatever may be the improvement in artillery, or " the progress made in the art of rendering a ship's sides invulnerable, "boarding will al ways remain as a last resource to decide otherwise in" conclusive actions at sea and cutting-out expeditions in harbour" and " boarders, to do their work effectually, must have that agility which " on board ship or in boats can alone be found in sailors.

"(3.) That readiness of resource which is largely dereloped in Eng"lish lads who love and follow the sea, and enables them when they "become men to contend with and overcome difficulties afloat or on "shore, and to anticipate or repair accidents witls a surprising " rapidity.

"These three qualities, when combined with that tenacity of purpose "common to all Englishmen, make up the distinntive character of truo "English sailors, whose presence in large numbers in our future naval "actions cannot be dispensed with if we desire to insure victory."

I may have appeared to some of my hearers to be digressing from the sulject announced at the liend of my paper. I must, if so, reply that I feel very strongly that one principal merit in the establishment of a class of ocean cruizers, to be actively employed in all parts of the world, would be its effect as an antidote to the listles; life engendered among men shut up in iron-clads, so constructed as scarcely to be trusted to move from one port to another without the aid of steam.

If such, then, be. the state of affairs with the seamen in the present day, neither are our younger officers trained in such seaman-like habits as was formerly the case.

Not only, in cant phrase, is the "schoolmaster albroad," but he now reigns supreme on board, in his demand upon the timo of the young gentlemen under his tuition.

The ships are very few and far between in which lads lave any opportunity of becoming thorough seamen, and the consequence is such a low standard in that respect, that I have heard a lieutenant speak of a youngster in commendatory terms, adding, as a kind of make-weight, "and ho is vory fairly up in his sailorising."

Then, owing to the paucity of lieutenants, theso same lads, who are examined and passed with reference to their opportunities of instruction and practice, become in their turn lieutenants in all the responsibility of that rank, without ever being properly "up in their sailorising." I heard of a large ship in the Channel squadron being tacked at night in a manner to cause the captain to remark upon it afterwards to the officer in charge of the watch, and it turned out that he had never in his life put a ship about until required to do so at night, when keeping station in company with other ships. 
Now, this is scarcely the state of things we can desire to see in the British Nary, and one grent remedy for it, in my humble judgment, would be the employment of such ocean cruizers as I hare endeavoured to recommend.

We are approaching to the state of the Spanish Nary, when it possessed, as was said, more admirals than seamen, for wo havo already more flag officers on the various lists than we have midshipmen. I refer to the Nary List for the numbers, and I find upwards of 320 officers bearing the title of admiral, as against 104 in the rank of sublieutenant, besides those who may be acting in that rank, and from amongst whom many are doing the duty of lieutenant.

The lieutenants, I find, are 20 per cent. below their estabished number, and it is from the trifling number of sub-lieutenants that the deficiency has to be made up.

Give us active cruizers, agnin I sny, to restore n senman-like spirit, skill, and activity among both officers and men. It is not yet too late, but who shall tell when it may be! and when the time of trial comes, little will it arail to seck remedial measures.

The classes of ships recently constructed in America would give employment to real seamen, some of whom being always in reserve in naval barracks, would be at hand to form a nucleus for manning with the Coast Guard and Naval Reserve those iron-clad ships destined to form the squadrons for liome defence on any emergency.

If the colonies maintained a sufficient naval force for protection of their coasts-which it is nothing but an impossibility for this country even to attempt to do for them-then the number of ocean cruizers might be reduced in time of peace, and a reserve of sueh ships maintained in readiness at home, could, in erent of war, be fitted out by degrees as the enrolled seamen returned from abroad, at the estimated rate of 1,000 a-montl, besides which, we may count for something the enthusiasm displayed, by the Northern seanen especially, at the time of the "Trent" difficulty.

It needs little argument before a professional meeting of this description, to establish the superiority of copper-bottomed ships for lengthened service in distant seas, over those of steel or iron.

In a lecture delivered at this Institution by Commr. F. Warren, on 20th March last, the annual expense of docking and varnishing the bottom of an iron slip of 3,700 tons, is stated as $£ 6772 \mathrm{~s}$. $8 \mathrm{~d}$., while the increased expenditure of steam-fuel consequent upon the foulness of such a bottom, so prepared, after less than six months' service, amounts to more than 25 per cent.

Considering the cost of coal on distant stations where this increased expense may be supposed to arise, this increase amounts to a very large sum upon even our iron troop ships alone.

In the "Megara," for instance, whose best speed is 10 lnots, her progress, whether under steam or sail, was impeded 1.5 knots per hour after only three months' service, and double that amount after six months.

Apart from the decrease of efficieney for general service, and large increaso of expense, wa lave to consider the positive risk of losing a 
slip, under circumstances whero this loss of motire porrer, whether expressed in speed or fuel, added to possible unmanageableness in consequence, might tell most fatally.

It appears, therefore, a sine quat non that ships for lengthened and distant and foreign serrice-and especially in time of war-should be free from the many objections which must ever attach to an iron bottom.

No substitute of any real merit among tho many contrirances tried or suggested, appenrs likely to supply the good qualities of the old copper bottom.

An iron clipper ship has been very successfully coppered by Messrs. Iustin, of which the details hare appeared in the public papers.

I have been told by a friend of the owners, who have patented their method of sheathing, that although no other slipowners have been induced to follow in their footsteps - probably deterred by a question of royalty on the patent-yet they (Messis. Austin) have been remunerated for the expense incurred, by the two first voyages of their ship, whose displacement and consequent carrying power have been so largely increased.

Of course the ratio of displacement to propelling power has to be considered in constructing a ship on this principle of $a$ wooden sheathing outside an iron bottom. But this is a trifling problem in the hands of a constructor.

The bottom of the ship has been tested by the removal of portions of the sheathing, and in all those plices, as I am informed, the insulation of the iron has been so complete as to have perfectly protected it against the destructive effects of the copper.

Finally, then, let these ships with steel frames, inside skins, woodplanking," and coppered bottoms, be provided with iron masts of great strength, and of large diameter, to withstand the effects of shot; let those masts be, as far as possible, independent of their lower rigging for support, by being built into and forming part of the ship; give them cap topsails and long mastheads, and I belicre they would combine the qualities required for long cruizes, beyond any other description of vessel yet produced. Fit them either with twin screws or else with feathering single ones, and balanced rudders, arm them with a few of the heaviest guns upon whose soundness you can rely, with some howitzers in addition for use at close quarters ; let them carry, perhaps, an iron belt above and below the water-line, but certainly an iron inner skin, and divide their. holds into water-tight compartments, and they may go forth in confidence to scek in vain for their superiors and to find their equals if they can. Such ships will, at the same time, increase the efficiency of the nary in quality of material, while also keeping alive the spirit of true seamanship anong both officers and men.

T'o resume shortly the purport of the present paper.

I desire to adrocate especially threo great principles, namely, the

On the Clyde, these union-built ships are constructed with diagonel planking in two thicknesses crossing at right angles, planed; they cost less than 218 per ton. This would be too cheap for the Rojal Dockyards.-W. II. 
adaptation of particular ships for particular duties; that the ships of each class should be as nearly is possible consimilar: and that speed, with an armament of large calibre should be the principle pervading all classes of ocean-cruizing ships.

Secondly, I wonld urge the importance of constructing, without a moment's loss of time, as many as the country will consent to grant, of ships on the pattern of the large American corvettes.

'I'hirdly, that such ships should be the menns and the occasion of keeping on foot a greater number of boná-fide scamen in the Royal Navy, whose expense could well afford to be deducted from that of the Royal Naval Reserve.

Such men would be of too great value to be inconsiderntely cast aside at the price of one farthing or less in the pound, of income-tax, and the Coast Guard should be maintained on an increased footing for their reception, not only for the sako of kecping on hand a Reserve very superior to that of the mercantile marine, but above all for the avoidance of that baleful eril which has so often arisen out of Parliamentary parsimony, namely, the want of good faith towards our scamen.

The more active employment of our officers would not only be a boon to them, but such cmployment as the class of ships which I have endeavoured to recommend would afford them, would prove an antidote to the prejudicial effect which the uso of steam, in ships fitted out beiorehand, has had upon the practical seamanship of almost every class in Her Majesty's Navy, as well as in the mercantile marine.

Nor these points only, but in erent of war, we should be in a Enitable position at sea to resist the depredations upon our commerce and our colonies, which will, in future conflicts with other countries, occupy the place of the great naval actions that adoin the history of Great Britain. 


\section{APPENDIX.}

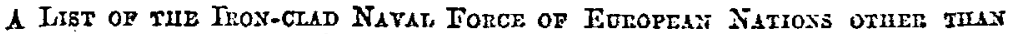
Great buimux and Fraxce.

Taken from "Statesnan's Tear Dooli" for 1660, and fion other sources.

ITALY.

4. Frigatca ........... cach Gums. Ir.p.

$7 \quad \ldots \ldots \ldots, 26,700$

2 Correttes $\ldots \ldots \ldots, \ldots, 20 \quad 400$

$2 \quad \ldots \ldots \ldots, \quad 12 \quad 300$

2 Gun-boats ........" 5 " 150

1 Cupola slip ....." 2 700 Total 31

18 ships

$\overline{102} \overline{10,900}$

In addition to the abore, the sanetion of Farliament has been obtained for the con. struction of $A$ other iron-clads. $-Q_{\text {urarterly }}$ Retievo, October, 1865.

2 Frigates.

Rossis.

22 Correttes.

I Clipper.

3 Batterics.

11 Coiled gun-boats.

14. Plated battericz.

53

Austria.
Prosath (Schemc).

Guns.

10 Frigates ............ 250

10 Turret ships ........ 40

8 Correttes $\ldots \ldots \ldots \ldots .224$

6 (...........

607

Sram (Scheme). Guns. II-p. - By decree of $A_{\text {pril, }} 1860$.

Desuratak.

4. Iron-clads.

Netnerusus.

Unknown.

Torkex.

O Iron-clads.

Guns. II-p. N.B.-Diferent States in South Ame. rica are also providing iron-clad ships of war. 
Almiral HALSTED : I would merely observe, upon the statement regarding the number of guns in our iron-clids as compared with the number in tho French ironclads, that Captain Horton has included all our guns, as if they wero all under armour. I do not think he has made the distinetion between armoured and unarmoured guns.

Captain IIonIos: They are the guns carried by armour-clad ships.

Adniral IIAISTED: In the case jou quote, of tho "Black Princo" and tho "Warrior," instead of 41 guns under armour, they have only 26. I see the "Defence" and the "Rcsistance" are put down in the list for 16 guns : it should be 14, they hare only 7 broadside guns under armour. Tho "Achilles" has orit? got 11 under armour, double broadside 22 . If jou take this point into consideration, you will see that we are much worse off, as compared with the French, than you have represented. What $I$ am stating is rather an addition to your unfarourable comparison. I would merely add, that I fully agree in all the general remarks you have made. But when you say your wooden ships hare an inch skin of iron, they are ins truth ships of iron, and not of wood ; in which case they may stand the effects of tho machiners, which is necessary to gire them high speed; but ships of rood could not sustain those effects. I do not beliere we posscss a singlo armed ship of wood which could really and truly put forth her powers of high speed, up to anfthing like 2,000 horses and upwards for any continuous period in time of war. There is no such thing in cristeyce as a screw-ship at the present moment in the merchant service built of rood, as the result of loná-fide experience. They hare all gono to pieces; and ours in the Navy would go to pieces too if they were really put to proof. But the fact is, we do not, in time of peace, continue running them in tho way, in which they would be required to run in time of war. Howerer, your proposed combination of an outside skin of mood, and an inside skin of iron might answer. I did not understand whether your frame was proposed to be inside or outside that shin of iron. To do any good, it should be inside in order to support the skin. Then, again, how are you going to apply jour wood? I belicre the Americans themselres would build of iron, and would armour their iron ehips as we are doing, in most eases, but they hare a great excess of wood and rery little experience in the construction of iron.

The Crairvar: Eon would jou dispose of the dilliculty of the bottom?

Admiral HaLsTed : I do not believe that it is a difficulty, for this reason; I nerer accept anything as diffeult whero suffeient means haro not been tried to get orer it. Its existence at the present moment can be got orer in the case proposed by Captain Warren; again, in the caso proposed by you; ngain; as proposed by Dr. Grantham; and so far back as the lectures which I delirered here in 1861, showing precisely the same erils, a national effort was suggested. It has long become a national question, inrolring a uational effort to get orer it. I haro noted here a remark of Captain IIorton, that the system of fouling is incritable with iron bottoms. But if $I$ understand him aright, he immedintely afterwards quoted ressels of Mfessrs. Austin-I think that was the name-where the fouling had been got orer.

Captain IIontox: I beg your pardon; one ship las an iron bottom, and tho other Inas a copper bottom exposed to the water, no matter what she has inside.

Admiral IIAISTED : I do not quite apprehend the difference which you haro made. At any rate it is perfectly certain that there has never been any national effort mado to get over the rery great eril which sou hare described. The special talent of the country, qualified to meet a difficulty of that sort, has verer been appealed to. It would be worth while to expend any number of tens of thousands of pounds of the public money, for the purpose of really constituting a committee of the ablest men to take up the question nationally. Up to the present moment, it has been left in the hands of individuals, who have been excited by thcir indiridual interesta to attempt it. But there has nerer been anything like a connected system, or attempt made of a public nature, to get orer it. Let me rerert to a circumstance which oceurred many years ago, when screr-ships were first introduced, and when the projection of the screw shaft under water was tho then means for connecting and disconnecting. The screw shaft projected bejond the stern-post, and ras exposed to tho setion of the cop: per. At that time it was found that Muntz's metal was tho matcrial which was least 
productive of the golranic current ; and so far back as the days of the "Amplion," in 1846 and 1817 , it was proposed to make all the stern portions of the ship, including the stern-posts and the mudder, of Muntz's metal. Ships at that time were ordered to be sheathed with Muntz's metal, on account of its materially decreased effect as a galvanic power. The ship I commanded was so sheathed. The object is so important, that there is no reason why MIuntz's metal itself, thicl plates of IIuntz's metal, should not bo substituted for iron plates. To gire rou an idea that such a thing has been practically contemplated, I may say that not many jears ago, it was made the subject of a patent. Upon an estimate it would hare cost for a ship of the size of the "Warrior" about $£ 30,000$ more, to hare construeted all her lower parts and ber outside plating cutirely of Mruntz's metal. I do not at all beliere that there is any permanent diffenlty about the businesz: I nerer admit that difficulties do exist to this great extent, unless they hare been firly, and to an equal extent, attacled by those who are competent to deal with them. I giro you great credit for the way in which you hare dramn up your paper. I belicre you have done a great public service by so doing, and I am tery happs to state my opiuions thus publicly upon the matter.

Captain IIosessos, R.N.: It is mith much pleasuro that I rise to say how much gratified I am with the paper just read. I cannot say that I agree with Captain Horton in erery paricular, but as a whole I hare listened with much pleasure to every trord that he has read. Captain Iforton has dwelt upon the importance of speed; but there is a rier of this question which.has seldom been taken by the majority of the profession. We all know that the horse-power required, is as the cube of tho velocity. To cnable me to illustrate this, I will take simple figures. I will take 10; the cube of 10 is 1,000, and the cube of 8 is 512, or about onc-half the cube of 10. It is thus secn that to pass from 8 knots to 10 knots requires double the horse-power. All parties admit this, but few think of the,rererse. If a galo of wind drires tho specd of a ressel clown from 10 knots to 8 kuots, practical experiments orer thousands of miles, as well as thcory, tell us that the ressel thus reduced from 10 to 8 will maintain an arerage of about 8 knots, whilo the ressel with a maximum speed of only 8 knots will, in the same proportion, be driven down to nothing. I do not know whether I hare made mysclf clearly understood? (Ycs.) You rill thus obserre the importance of obtaining the average speed of a resscl as shomn by her runs in the open ocean, subject to lieary seas and wind, and not bo content with any comparison obtained at the measured mile in smooth water. Admiral IIalsted has alluded to the fouling of the bottom in iron ressels. That becomes an ingredient in the speed, for when that foulness takes place, the adrau. tago derived from a higher power is effectually destrojed. When I was in tho East Indies, Captain Potts can o out from England in - Jmmand of tho "Malta," a fino new iron stcamer, belongi.ig to the Peuinsul. and Oriental Company. Ire, like erery sailor, was in lore with his own slip, and stated the high arerage specd that his steamer had maintaincd from Singapore to IIong Iong. I beliere the speed stated was 12 hnots an hour. I had always reported the "Inflexible" to be a slow bost, considerably underporered and undermasted. The Admiral ssked mo if I could "beat that." "Oh, no," I replied; "if the "Mralta' has areraged that speed, the "Indexible' cannot beat lien:" We had a trial of speed, howerea, before the "Inlexible" left the station, in a run from IIong Kong to Singapore, and thence on to Bombay, against the șouth-west monsoon. You must bear in mind the adrantago the "Mralta". possessed in haring erery arraugement made for immediate coiling on her arriral in port. I had to land, and to make erers arrangement subsequent to my arriral. Nererthelesa, I beat her eight dajs on tho run to Dombay. The adrantage I gained over.her was two dajs in the smooth mater between IIong Kong and Singapore. It was the foulness of her bottom alone, I beliere, that enabled me to beat her to that extent, as was shown when she went into dock at Bombay. On the other haud, when the "Inflexible" was taken into dock, after. having been in commission cightecn months, and just after maling a run of 9,000 miles from New Zealand, her bottom was perfectly clean. It is important to state that three ressels ran in this race-the "MIalta," the "Infexible," and the "Fury." All started within a few lours of each other, and cncountered the same meather. 
Both the wooden ressels beat the iron ressel in this decided manner. The "InHexible" land an adrantage orer the "Fury" in this portion of the run of half $a$ mile an hour. The latter did not go bejond Singapore. Now, in the construction of these megnificent ressels, which are eaid to cost from $\$ 250,000$ to near $\$ 400,000$, I think there ought to be some more experimental trial than the measured mile in England. They ought to be tried orer given distances in the open ocean, where alone the true arerage speed can be obtained. Sone of the large iron-clad steamers on Captain IIorton's list appear to hare a very low rate of speed. If this is the result of their trials at the measured mile they will most likely fail to make cren a mile of headway when cncountering adverse winds, and a heary head sea. I read lately in a daily paper that an official in the French Marine had reported that some iron-clad ressels lately launclied had suffered so much frcil corrosion, that ho anticipated they would require to be replated erery fire years. I cannot say if this statement be true or fulse. It is, howerer, no argument against the construction of these monstrous ressels. We must hare them so long as other nations hare them. At the same time let us build resscls such as are proposed by Captain Ilorton, that will:do the duty which the "Alabama" did-paralyse the whole commerce of tiic encmi, and protect our omn. I entirely agree with Captain Horton that esch class ought to lare a speciality. Tessels of certuin classes ought to be built for certain specified objecls, and it ought to be clearly established by experiments obtained orer giren distanes in the open ocean, that they can fulfil erery condition of the class for rhich thes are infended. Our inports and exports last Jear were 414 millions, and this ycar will be close upon 500 millions; and, ccrtainly, we ought to harc something to protect those rast commerciul interests. (Hear, hear.) We are fully in a position to protect our own consts, but let the Administration 8 s., if war were to break out to-morrow, whether we slould be able to protect our rast mereantile marino from the attacks of an enemy.

Mr. A. F. RIDGW which $I$ think of rnst importance, and that is in regard to our colonial defenecs. There is only onc of the colonies which, as yet, has attempted to hare a nary, and that in a rery small was-the colony of Yictoria. There was a ship built here, and cent out to that colony a few years ago. The gentIeman who las just sat down spote of New Zealand. In Now Zealand the necessities of the war hare called up the encrgics of the colony in ship-building, and in manufacturing stenm-slips. I an very glad to see by the papers which arrired recently that a ressel built for mercantile purposes, named the "Tasmanian Maid," bought by the Iocal Gorcmenent, and christeued the "Sand Fly" and other ressels that mere emplojed in the sorvice of the Gorcmment in the late operations hare been well supplied witl coal raised in the colony. There hare been immense discoreries of coal in Nicw Zcaland, so that ships cmployed by our Gorernment out in those colonics could be well supplied with conl. Then, there are rery large deposits of iron-sand all along the coast, which partics are now setting to work to bring into the shape of jron; so there is no lack of iron to build slips of war. There are a great number of places on the const whero ship-building can be carricl on extensircly. 1 great many shipwrights 5 om Norcastle-upon-Fyne and the northem ports hare gone to New Zealand ad the building of slips is becoming a considcrable trade. The ressels that run into Sydney and Auchland are sereral of them of large size.

Captain Jașper SeLKr, R.N.: I think, MIr. Chairman, I must claim a fow minutes to speak on one or two principles which Captain IIorton has so rery ably put before us. Ilis paper has been so comprehensive that I think erery one will agree with me that it deserres a longer discussion than time will permit. Mowerer, it is necesary that we elould look at this formidabla array of a forcign nary in all the lights, if possible, to which it may be subjected. I confess that in his beautitully arranged list of French ressels of 900 horse-power all through, and of 16 guns, I sen something which reminds me of that dead lerel of mediocrity which is generally the result of a settled plan closely stuck to. Whereas in this country, although we hare committed rery great errors in armoured ships, and I hare been among the rery first to admit it and to point it out, yet we are going forward; while the French appear to linte limited themselres to a type which they conceired, and which they 
are prepared to defend, as being perfection. When I remember that a ship which $I$ do not fec in the list, the "Hercules," has adranced to nine inches of armour, and with a probable speed of not less than that of those which now carrs the rery ineff. cient thickncss of four and a half inches, I think we may say that we hare mado an enormous adrance, and one for which uniformity may very well be sacrificed. If we can go forward in that direction, if we can obtain a still further adrance in the use of steel for the hull, which gires us the power of carrying so great a weight of armour without unduly diminishing the speed or the other qualities of the ship, I think we are bound to do so. If, again, we only consider the dificulties of the galvanic problem, which has not jet been attacked as well as it might haro been, but which is in process of solution, wo shall find that much remains to be done before we reach the limits of the adrances that we ought to make. I see one Officer of the Royal Nary present who has attacked this problem with a large measire of sucecss; and I know sereral other inventors who do now practically prerent fouling and tho decay of the iron. They do it by the adoption of a two-fold principle. Where you desire to prerent fouling thiere must be a slow decay of the surface; and where you desire to prerent decay of tho bottam, some other material, the application of a pigment to the outside, must be resorted to. In these two things the necessary conditions will be obtained. The bottom will not decaj, because jou have arrested tho action of the galvanic current; and fouling will not take place, becuss you hare provided against it by a process which will prerent the adbesion of grass and barnacles. The answer to the proposition for the establishment of an un-armoured class of ressels maj be found in the fact that we possess alraady such an un-armoured class of resels. If we desire them, we hare a merchant nary which we could arm with such few guns as may be necessary, and which we could employ satisfactorily without pretermitting any of the adrances which we are making in iron-clad ressels, which are an ineritable necessity where flects aro to act against. feets. It would be rory unsatisfactory to an offecr of the British Nary if, fincling himself in c.mmand of an unarmoured ressel, he was opposed to one of those wretehed little armoured tubs, which it would not consort with his dignity to run away from, and which he would fight at an unormous disadrantage. (Hear, hear.) The question of ehanging ships which Captain Horton has spoken of is one which he may not hare remembered would introduce much more of that undesirable material, foolseap, which has come into the nary in such floods of late jears. I doubt rery much whether any set of Admirals could keep their brains under the strain which would bo thrown upon them by the constant change of ships, ollicers, and creything else connected with their command. I do not agree with Captnin IIorton's riews about the turrets. I beliere these turrets are excellent things in their place; but that they will compete crentually with broadsido armoured ressels I do not believe, for this reason, amongst other3, that although a very good show is made when turret-ships are only plessed to figlit one side, and all their guns are pointed on that side against a single enemr, yet when it comes to a fight with both broadsides that is quite another affair. Then the weight of metal thrown is by no neans equal to that that would be thrown by a brondside armour-ship. Also, because in the necessity of the case, the ship requires to be armoured as well as the turret; therefore, you aro devoting one special armour to the guns, and another special armour to the hull. We might haro cause to take a gloomy riew if we were once to admit that the superiority of the Fiench and American naries was so far established as these figures tend to show. In the caso of the French nary, I think, wo should hare cause for doubt and distrust; and with regard to the American nary, we should recollect that they, like ourselves during the Crimean War, built a rery large number of ressels for the special purposes of their war which would not be of the slightest importance as against us; and that the question of the "Alabama" and her consorts reduces itself to this-that any nation, not possessing any nary whaterer, nerer haring had a nary previously, tho Chilians at this moment possessing three or four ships only, may, by sending one fast cruiser to sea, whose mission is not to be caught, but to catch the commerco of tho enemy, send up the rates of insurance in tho country against which the attack is made, and her flag disappears from the sea. It is not because all the ships belonging to the country attacked will be caught by that resocl, but it is because any of the 
Elips may be caught by that ressel, therefore the rates of insurance go up; and it is felt better not to ecnd your onn ships to sca, but to put your cargo under the fla: of another nation. With regard to the twin-screw system and turrets, I must also beg to remark that in this Institution two of its distinguished members hare been respectirely the consistent adrocates for some years past of these two things; but I do not think it $a$ compliment to them that their efforts should be taken bold of by a department of the State, without acknowledgment of any sort, be called by another but slightly altered name, and brought form ard as the unaided efforts of the genius of that department. I hope the country is of opinion that whenerer a man has prored his point fairly, after the rers grcat discouragement which all inventors mect with in this runtry in their first efforis, that he docs then deserro to be publicly recognisct, and not to hare his efforts stolen from him, or abstracted from him in any sort of way. I hope that what we sny in this Institution will be so far re-celioed $3 s$ to convince those gentlemen who hare the management of these affairs that their best policy is to scel for aud openly praise that tulent which they may often find by applying to the members of the sister services for their ideas on points in which such men are most experienced, and in which some among then hare shown speciul knomledge, tind have taken special interest.

Mr. E. J. REED, Clicf Constructor of the Kary: I am not quite arare of the exact purport or intention of the last remarks of Captain Selwyn, but I quite concar in the principle that when you can trace an invention to an individual inrentor it is a duty, to reward that inventor. Captain Selwyn's rentarks have fery mucl taken away the ground upon which I was about to stand for one or two moments in speaking of Captain Irorton's paper. It secrns to me not at all likely to influence public action wisely when comparisons between the naries of this and other countries are introduced on an unfair basis, or a basis which wo should not recornise as is suficient basis for comparison, when dissimilarities in ressels, dissimilarities in potrer, dissimilarities in armament, and dissimilarities in tonnago aro adduced as necessary disadrantagcs. Captain Selwyn has already pointed out that the uniformity in the Fronch nary points to something like mediocrits. I think wo are scarcely furnished with the funds necessary to pursue uniform systems with the improrements which are continualls taking place in guns and ships. I am not at all prepared to say that the full amouit of desirable uniformity exists in our ships, but I do say that some of the greatest dissimilarities that exist between them are due to justifiable causes. I will instance one or two cases. Among the list of first-rate ships on the wall we find there are ships which are dissinilar only because a recent change has not come under the notice of Captain IIorton. I thinls the "Northumberland". will hare a less number of protected guns than the other two vessels of her class. Nom, why will that ressel lure a different mumber of guns? For this reason, that the ship has been a long time in building, while armour plating has increased in thiclness, and guns haro incresed in porrer, and it was deemed adrisable to arail ourselres of the backward state of that ship to place upon her thicker armour, and an inereased calibre of guns in her batterg. Nor, I can hardly imagine any officer of the nary censuring a change of that kind, unless it in rolved an objectionable principle in construction. I merely say that the diserepanes that will exist between the thiekness of armour of that slip and of other ships of her class, and the difference between the armament of that ship and of other ships of licr class, can hardly be made a ground of complaint. I lardly think wo should bo in a better position if wo had adhered to the idens which prerailed at the time she mas begun to be built. More thin that, $I$ am disposed to think that, when resscls with a rery large increase in the thickncss of their armour, and a tery large increase in the power of their guns, are brought against ressels with smaller guns and less armour, as in the French navy, that they + will produce the same consternation as an armour-plated ship rould originally hare produced among a fect of non-armoured rcsscls. It appoars to me that it would be deplomable if the weight of an Institution like this should be giren to impede the efforts made by responsible persons to increase the porrer and effeiency of onr ships. Again, I may point to the circumstance that mentioning the nominal horse-power docs not point to a considerable discrepancy of speed or power. I will illustrate that refuarle in this may: In tho case of the "Lord Clyde," which jou find 
of the sume"nominal horse-power as the "Prince Consort" aud the "Caledouia," here engines are upon a new principle which developes a larger power than the engines of other ships. What is the consequence of that? I'hat by rurtue of that increase in effectire power, though of the same nominal porer, that ship is cuabled to carry five and a half inches of armour at her water line instead of four and a half, and an extra inch and a half orer lier gun deck; her armour also extends further benenth the water, she has higher ports, and it is supposed she has other adrantages in comparison with other ships of tho same nominal power. For, I submit whether any one rould be prepared to maintain that tlie "Lord Clyde" is a worse ship because she has at different type of cugine, which cuables tis to give her increasch weight of amour and increased weight of guns-worse for no other reason than that if you compare her with other ressels of the same nominal horse-poner she differs from them in armour and guns, Again, with regard to the armour of the French ships, it is perfectly erident that if the efforts made in this Institution and otler places to improve the porrer of guns, which is more or less associated with the increase of weight of guns, if these efforts are right there is only one ray of utilising the ships you hare, that $i$, by putting into them guns of increased power with a Icss number of them. Ships are things that jou camot put guns of twenty tons in place of guns of ten tons into, and hare tho same number of them. I think it is liardly a fair ground of ecnsure that you hare been putting ten guns in one ship in place of twenty in another, when you haro been increasing the power of that ship by putting in guns of larger calibre. Then, I think it is unfair to sas that the French nary is a supcrior nary to our own. While they hare ships uniformly armed with guns that fire a low charge of powder, we are arming other ships with guns that fire $50-1 \mathrm{~b}$. chnrges of powder. I consiler the uniformity is a uniformity of mediocrity, a thing not at all to be desired; and I think we nay congratulate ourselres npon the fart, that in this country we hare licen enabled to increase the power of our ships, eren if with some disregard to mere cniformity of figures, I should like to make another remark which is only fair to the nary; that is, that those ships giren on the board are not so dissimilar as represented. The "Caletonia," the "Occan," the "Prince Consort," the "Roral Alfred," and the "Royal Oak," are all built from precisely the same designs. The three ships, "Caledonia," "Prince Consort," and "Occan," are as much alike as three ships can possibly be. They differ from the others in tho amount of their power; and recently the "Rojal Allfred" bas been made different from her consort by the substitution of thicker armonr and larger gums. But those threo ships which hare precisely the same porrer are to all intents and purposes alike. Erersbody knows the "Warrior" and "Black Prince" are substantially alike; and if there is any discrepancy in their armament, it is only because you cannot, with the improrements that are going forwarl, produce the new guus so quickly as to put them into crery ship. Some remark has been made about our ships not being adapted to work in squadrons. In a letter which I rrote to the Times nemspaper tro or thrce sear's ago, I showed that there are a lange number of these ships perfectly eapable of workiner in squadrons. But ressels built alike often differ much from each other. The "Scorpion" and "Wirem" appear to be cxactly alike. They are the two turret ressels supposed to havo been built for the Confederntes by AIessrs. Laird; those ressels are built from the sane designs, jet the "Scorpion" and the "Wirem" differ half a knot in speed. Frerything is alike in other respects. I have not with me the speeds of all those ressels mentioned, but if you were to group them rou could put them in speeds differing not more than from lalf a knot to a knot. It wonld be nseless to think of improring the speed of our ships if a difference of a knot or half a knot is to be considered an insuperable objection to the working of our ships in squadrons in time of war. There was auother remark mado by Captain Horton. He has discussed the question as if we had no ships at all capable of crosing the seas and disposing of such potrerful vessels as might be sent against our nary. I fully agree with Captain Forton and the other gentlemen who hare admitted-and people are obliged not only to admit, but to feel with great pain sometines-that the irou slips are eubject to more or less dininution of speed; but any one knowing those ressels must be awaro that ships like the "Warrior," the "Black Prince," and all

FoL, $x$. 
those larger ressels are just as capable of making a rogage across the ocean, and of doing, in fact, all that the un-armoured ressels could do, as any ressels which wo might possibly build. I do not say this in depreciation of Captain Horton's main points, because I am rery much impressed with the desirability of building ererything in adrance of what las been done beforc. It sems to me a legitimate use of the wealth of this country to learn what other people are doing, and then, if possible, to make ererything in adrance of them. I shall not, perhaps, be exceeding what is allowable under the circumstances if I mention what Captain IIorton has not been at liberty to mention, namely, that the construction of a class of resscls, such as he has been projecting, has been scriously entertained. But, unfortunately, there are great difficulties in the way. Tou know perfectly well that it is not an easy thing to build a ressel to steam 15 knots. One of the American ressels mentioned this erening by Captain IIcrton has keen put formard by the builder as capable of 15 knots. The American Gorernment, howeres, do not beliere in her. They have undertaken to pay the builder in full for the ressel if she will make 12 knots an hour; and they have, moreorer, undertaken to pay him in proportion to the cube of the speed between 12 and 15 bnots, so little confidence hare they in the statement. There is one general consideration which ought not to be lost sight of,-that neither the French ships nor the American ships have engines cqual to the engines in English ships. The American cngines are much hearier than ours; and it is chiefly on paper in this country that they steam their ressels at rery high specds. We could do the same if we chose. I think no dependence can be placed upon figures on paper as to the speed of their ressels. It should be borne in mind that crery ship built by the Admiralty is subjected to the sererest trinl of speed on the measured mile, which I ngree is not and ought not to be a final trial. But it is a desirable trial, because it gires you comparatire capabilities. I slould hare been glad if those ressels in the French navy which are said to steam at a speed superior to ours conld hare had a race with some of our ressels at the international meeting at Portsmouth, the "IIagenta" with the "Warrior," for instance. My onn opinion is, that the French ressels do not equal ours in spead; jet, on the other hand, I must say that I beliere the deficiency in speed would in many instances be compensated by the extreme handi. ness which the slorter ressel has. Iforrerer, $I$ do not think it fair to lose sight of the fact that these gencrnl representations aro exaggerated with regard to the speed of ressels of other nations; and that the American ressels hare jet to do the extra. ordinary speeds of which we hare heard so much. I hope my remarks will be taken in the spirit in which they are made, in the spirit in which this Institution promotes the discussion of these questions. I am sure that Captain Horton will fecl that in making them I have no desire to detract from the main value of his paper. On the contrars, I am reryglad to find that officers of lis ability and experience do contribute thcir riews on these important matters. But I think naral oflicers would do extremely well, if they wish their words and facts to hare weight with the State, to take pains to analyse their facts and figures, and gire us a basis for ererything they say, on which we can proced practically.

Captain IIontos: I am obliged to IIr. Reed and other gentlemen for such con. currence as the hare expressed in the riers I put forward, especially as my object is to adrocate the preparation, which Mrr. Reed has hiudly informed us is under consideration, of un-armoured ships. They mas fail as much as the American ships hare failed; still, what $I$ wish is, that the attempt should be mado to produce a class of ships competent to cope with thoso which are prepared in America with a definite object, namely, the destruction of our commerce. We, on the other hand, should be capable of protecting our commerce against such depredators as they might turn ouf. Tho commerce of this country $\pi$ ith our colonies, on the high seas constitutes one of our meak points. With regard to the figures I hare put on the board, I stated in my paper that I was under correction; that they were put there for the purposo of comparison; but I cannot rouch for their accuracy. Afr. Reed has the adrantago of knowing facts which aro foreign to me. I have merely taken them from such documents as I can find. The French ships $I$ have illustrated in that tablo possess an uniformity, from which they appear to hare a gront adrantage in squadron sailing, of whilh our ships sce so little in the present das. It is satisfactory to learn that 80 
many of our ships are so nearly alike. I hare counted the varictics which do exist among them, and I find there are cleren classcs in respect of guns, ten classes of horee-power, and nine classes of tommage. Among those there may yet be great uniformity; and if Mr. Reed will kindly indicate to me those which form the same hind of squadron, it may be of great interest and ralue to the meeting.

MIr. REED : The first six would go together in point of speed, down to the "Black Prince."

Captain Ifontox :-Did you not mention four of the wooden ressels?

Mr. REED : "The "Caledonia," the "Lord Clyde," the "Lord Warden," the "Prince Consort," tho "Ocean," those fire; and screral others might bo named.

Captain IOrTox : 'Then we mar congratulate ourselres upon haring tro squadrons of powerful ships. The stronger ther are the better. I ain not an adrocate for suediocrity, but for improrement, though not simply for single ressels being inprored in their good qualitics, but also for those of inferior quality being improred up to a better standard. With regard to my idea of the "Union" for"m of building, they are slips composed of stecl frames. Inuer stins also, wood planking, stecl beams, and steel deeks would be a great protection to our crews. Captain Selwyn mentioned the possibility of fitting out merchant ships. Erer since the Peninsular and Oriental Company iras founded, and the West India Mrail l'acket Company was formed, it was one of the conditions imposed upon them that their ships should be capable of carrging guns. But, surely, those are not ships that would bo sent forth on a long cruize to contend with the American ships of which I epoke. I do not adrocate wooden ships or auy particular form of ships, but simply a general principle. But I think the transfer of the commerce of this country from our orn to a foreign fag would be about the most miserable condition of things this country could erer vitness; not only unfortunate for our position as a untion, but it almost implies starration. We should hardly get things from our enemies-supposing we were at war with $\Delta$ merica; and had to rely upon foreign flags-unless it were that our om ships were transferred to foreign llags, and $I$ think we should be searcely rell off in that case. MIr. Ridgeray faroured us with information that the colony of Tictoria is setting an example, which I hope will be quickly followed by other colonies, that of forming a nary. That is a question of state upon which I mercly touched. With the professional topic of ships $I$ am more capable of dealing. I do not know that there are any other objections raiscd which require a particular reply. We are told that certain things are in progress, as also certain measures for protceting slip's bottoms against corrosire decay and ngainst fouling. We do not posscss these things at present ; but we do know that copper sheets do protect ship's bottoms against fouling, and I think we should arail ourselres as far as possible of things existing rather than of those in prospect.

The Cnamras : I would take this opportunity of relieving Mr. Reed's mind by stating that this Institution is not embarked in any desire to foster or forward any wrong opinions. It is distinctly stated on the outside of the journal that the writer of erery paper is responsible for his own opinions. . The members of the Institution. are not at all committed to them. The miter states his own opinious here, and then they are open to be objected to by anybody. Ererybody is entitled to take objections. This regulation. is made in the hope that discussion will be brought about. We sometimes like to sce an adrerse paper, although the generality of us may not be farourably inclined to the viems contained in it, for the rery purpose of clucidating what is tho truth. I confess I think $M$ r. Reed is very hard on the writer of the paper, inasmuch as I did not understand the object of it was to set forth the superiority of the French, but mercly to adrocate one simple principle. II was not contrasting slip with ship, and saying that the English ships nere inferior to the French, but that in them thero was system, design, which it was desirable to hare, for slips acting in equadrons. Mr. Teed inust be rers sensible that, in case of accident, to haro a number of ships in squadrons and all these ships with different hinds of engines, and different in their coustruction in crery way, is, of course, $\dot{a}$ disadrantage. I onl 5 understood Captain Iforton as taking that viem-(Captain Horrox: Simply)-as desiring to hare a fixed pattern; not at all adrocating mediocrity, but progress; and that as a main feature - for that in reality was the main object of his paper-adrocating that class of 
ressel that he enlarged upon, which the Americans are building, and which Mry. Iieed admits is now in courso of construction, thus recognising tlie principle. Captain IIorton dwelt upon that, and Mr. Reed admitted it. I do. not know that unybody here except Captain Selwyn spoke of the introduction of steam-packels.

Captain SeLwXX: Not stcaun-packets ; ressels fitted for such a purpose.

The Crammix: To take the ordinary packet-ships from their regular ecrvice I think would be a rery great injury, not only to trade, but to the postal arrangements of the country.

Cuptain Serwrs: Pardon me; I said that in our merchant nary, not confining it to the great Steam-packet Companies, or any particular class of ressels; there are such resscls to be had if yon adreritso for them.

Ciptain Irosesso:" May I allude to what you hare sidid about these ships? I happened to be out is Indin when a sceret order eame from the Govermment to the I'ninsular and Oricial Company to arm their ressels. I was the only naral oflecer there, and I found the greatest possible difleculty in making those ships arailable at all.

The Cinansias then proposed the customary rote of thanks to Captian Horton for his paper. 